Dušan Jerotijević ${ }^{1}$

Živanka Miladinović Bogavac ${ }^{2}$

University "Union - Nikola Tesla" Belgrade

Business and Law Faculty, Belgrade

Dragana Nešović ${ }^{3}$

University "Union - Nikola Tesla" Belgrade

Faculty of Law, Security and Management "Konstantin Veliki ", Nish
SCIENTIFIC REVIEW ARTICLE

doi:10.5937/ekonomika1901067J

Received February, 19, 2019

Accepted: March, 15, 2019

\title{
ARBITRAL SOLUTION OF INTERNATIONAL ECONOMIC DISPUTES IN THE CONTEXT OF INTERNATIONAL ORGANIZATIONS IN CONDITIONS OF INTEGRATION PROCESSES
}

\begin{abstract}
In the modern world, great attention is paid to integration processes as an imperative for many world regions, where within these regions countries join in order to exchange comparative advantages and strengthen their economic positions within the integrated area, as well as outside it. The reasons and motives are more, everyone sees their chance to boost economic power, while underdeveloped countries or countries in transition see their chances through the various privileges and reputations that such associations receive. However, as in all other social relations and in international, especially economic, there may be disputes, whose resolution, due to the specific nature of such relations and disputes, led to the development of a system of special and selected arbitration courts. The paper also analyzes the specific position and legal personality of international organizations, in order to apply the rules on their responsibility in resolving the disputes in question. By establishing the legal personality of international organizations in the establishment of international legal and economic relations, i.e. the ability to take on rights and obligations in their own name, their responsibility for non-respect of rights and non-fulfilment of obligations in the international law order are also established.
\end{abstract}

Key words: international organizations, international disputes, arbitrations, legal subjectivity of international organizations, responsibility of international organizations, integration processes.

JEL Classification: K22, K29

\footnotetext{
${ }^{1}$ dusanjerotijevic@gmail.com

${ }^{2}$ zivankamiladinovic@gmail.com

${ }^{3}$ dragana.nesovich@gmail.com
} 


\title{
АРБИТРАЖНО РЕШАВАЫЕ МЕЪУНАРОДНИХ ПРИВРЕДНИХ СПОРОВА У ОКВИРУ МЕБУНАРОДНИХ ОРГАНИЗАЦИЈА У УСЛОВИМА ИНТЕГРАЦИОНИХ ПРОЦЕСА
}

\begin{abstract}
Апстракт
У савременом свету велика пажњ а посвећује се интеграционим процесима као императиву многим светским регионима, где се унутар тих региона земље удружују с ииљем размене компаративних предности и јачања својих економских позиција унутар интегрисаног подручја, као и ван ьега. Разлога и мотива има више, сви виде своју шансу да појачају економску моћ, док неразвијене земье или земље у транзицији виде своје шансе кроз разне повластице и репутащију које таквим удруживањима добијају. Међутим, као и усвим другим друштвеним односима иу међународним, посебно економским, може доћи до спорова, чије је решавање, због специфичности таквих односа и спорова, довело до развија система посебних и изабраних арбитражних судова. У раду се анализира и специфичан положај и правни субјективитет међународних организација, ради примене правила о юиховој одговорности y решавању предметних спорова. Утврђивањем правног субјективитета међународних организација у заснивану међународно-правних и економских односа, тј. способности да у своје име преузимају права и обавезе, утврђује се и юихова одговорност за непоштовање права и неиспуњавање обавеза у међунардноправном поретку.
\end{abstract}

Кључне речи: међународне организаиије, међународни спорови, арбитраже, правни субјективитет међународних организаиија, одговорност међународних организачија, интеграчиони процеси.

\section{Introduction}

Entities of international law are all persons who can be the bearers of rights and obligations in the international legal order, first and foremost those are states and international organizations. However, the subjectivity of international organizations is in many respects distinctive. Likewise, the international legal status of international organizations varies from case to case. The quality, nature and scope of the specific international legal subjectivity of international organizations is not identical and depends on the specific, both constitutive and functional characteristics of the organizations themselves. So, for example, the international legal subjectivity of the UN and the Council of Europe differs in terms of, activities, goals and membership, even though they have all the same constituent elements. On the other hand, subjectivity, OSCE in relation to the previous two organizations is even more distinct, and when we add to this the issues that arise in terms of the international legal subjectivity of the European Union, we can see how this is a really complex question (Savić, 2016, p. 176). Namely, the European Union, although it has elements of an international organization, today constitutes a 
specific federation of federal states, or of a confederal character (Vukadinović, 2006, p. 79-103).

Integration processes, as an important element that marks international legal and economic relations in the contemporary world, the issue of subjectivity and the responsibility of international organizations are, moreover, legally complicated. Given the motives and goals, it represents an original historical phenomenon that begins after the Second World War. Since then, the development of integration has been taking place uninterruptedly throughout, practically in all parts of the modern world. Concerning content elements, some specific integration units have already entered the phase of building complex and diverse management systems (EU), others put emphasis on marketbased interconnection (ASEAN), while others insist on the effects of interdependent division of labor (NAFTA). In addition, the fact that integration processes continue with unlimited intensity in terms of deepening, especially the economic content of their connection, should be added.

It is precisely from the positions of significant achievements and the future course of this process that we can estimate that integration processes are, at their core, a progressive historical phenomenon. The basic guiding idea is to create a maximally liberal market economy that best fits private capital and the basic sense of its existence. In addition to this, there is also a range of concepts of integration. It is known that integration leads to unevenness in economic development, as well as significant instability. Following these dangers, transnational organizations have been gradually formed, as well as the necessary means by which they influence the more balanced development and harmonious social division of labor. The question arises as to whether an integration can exist, and at the same time it does not have a discriminatory character, if it is known that they are created primarily to protect and foster the interests of its members.

Likewise, as in all other social relations and in international economic relations, there may be disputes between the parties in the economic relationship, the subject of the contract, etc. In such cases, mechanisms are needed that can enable the settlement of disputes. Of course, in those cases available to the parties to the dispute are those mechanisms that are otherwise available for resolving disputes in any conflicts, or appropriate courts.

However, international economic relations are somewhat specific, primarily because the affairs in these relations are based primarily on the agreement of the will of the parties involved in such relations. This freedom of will implies that the parties to the dispute themselves decide on the manner of resolving disputes that might arise from such relations. This led to the development of a system of special, selected courts, an arbitration in international economic relations. Moreover, arbitration proceedings are the prevailing way of resolving international economic disputes. This, furthermore, implies that there is a high degree of commitment to their decisions, that is, that the parties to a high-level dispute recognize the decisions of those elected courts.

This led to the undeniable fact that international or national arbitrations today are the prevailing way of resolving international commercial disputes. Although neither the international courts have lost any significance in this regard, it is undisputed that arbitration has far greater significance in resolving international commercial disputes from courts (Starčević, 2007, p. 71). 


\section{Previous determination of the concept of legal subjectivity of international organizations}

\section{Definition of international organizations}

In the doctrine of international law there is no generally accepted and comprehensive definition of international organizations that would apply to all organizations of an international character. This is not surprising given the wide range of organizations that can be considered international organizations under international law. That is why it is often resorted to by listing those elements that are substantially determined by its international character. One of the most commonly used definitions is conceptually determined by international organizations as a permanent form of cooperation among states established by agreement, in order to achieve a common goal and which has autonomy in relation to states, with special bodies whose function is to fulfill the goals of the organization (Encyclopedia of Public International Law, 1995, p. 1289). A similar definition can be found in other authors who designate international organizations as "the collectivity of states established by an international treaty, with the statute and common bodies and subjectivity different from the subjectivity of its member states, which is also a subject of international law with the power to conclude international treaties." The International Law Commission-ILC, in its Article 2 (a) Membership Plan, determines that the term "international organization" refers to an organization established by a contract or other instrument governed by international law, which has its own international legal personality. International organizations as their members, in addition to states, may include other entities. It is precisely this definition of the concept of an international organization that has common characteristics relevant to their responsibility for acts contrary to international law. Therefore, one should not seek to define the concept of an international organization in order to apply it universally, but so that their conceptual determination is of a purposeful character, such as the need to apply the rules of international responsibility of such organizations.

\section{International organization as a legal entity}

Since only subjects of international law can bear responsibility for unlawful acts, the presumption of international responsibility is possession of international legal subjectivity. For a long time, states were considered the only subjects of international law. However, the creation and multiplication of international organizations necessarily posed the question of their international legal subjectivity. With the responsibility of states for unlawful acts, the question of subjectivity is not raised, because they are the primary subjects of international law. When, in particular, it is a matter of the legal personality of international organizations, we can say that for a long time in legal theory there were no harmonized views, especially in details, on whether, to what extent and which international organizations are subjects of international law. Therefore, in international organizations, the issue of possession of international legal subjectivity is a prerequisite for applying the rules of international accountability. The legal subjectivity of international organizations, regardless of all differences and specificities, can be determined through several important elements. First, it is the existence of formal legal conditions for the emergence of concrete international legal relations, which international 
organizations provide through their actions on the basis of conventions, agreements and administrative acts. Secondly, international organizations, through the functioning of their bodies, decide independently, regardless of the will of the Member States that established them, and not on their behalf, but take concrete actions in their own name and for their own account (Krivokapić, 2011, p. 104). Then, we can determine the legal nature of international organizations by observing its constituent elements, which are essential for the existence or absence of a legal entity of an international organization. By formulating the constituent elements, they acquire legal and business capacity, which means they have the capacity to be the bearers of certain rights and obligations in the international legal order and can independently participate in international legal relations as legal persons. This further means that they have international legal personality, that is, they can be considered as subjects of international law. However, the nature and quality of their international legal subjectivity are specific, and their legal personality in the international legal order has certain formal legal restrictions because they do not possess procedural and delictal ability in the full sense of the word (Savić, 2016, p. 177). The limits of their legal and business capacity are determined by the states when concluding the act on the establishment of international organizations defining the scope of activities of the international organization. It is the founding act and its entrusted activities within the framework of the legal and business capacity of the international organization itself. The complexity of the legal issue of the international legal subjectivity of international organizations completes their special status both in terms of the internal law of the state on whose territory the seat of the international organization is, as well as the special legal order of its members. At the same time, it must be one legal personality, both in internal and international law in general. It can be concluded that the issue of the legal capacity of international organizations is not problematic, since it is acquired by itself by the very founding itself.

Problems arise in determining their business ability (Lukić and Košutić, 2006). In the legal theory, it is generally accepted that one person, entity, organization, etc., in order to be considered a legal entity, must simultaneously integrate legal and business capacity. Therefore, it is not disputable the issue of an international organization as a legal person in internal national law, because it is, in this sense, a subject of law. However, despite the legal complexity and all open dilemmas about the quality of international legal subjectivity, we can conclude that international organizations possess concrete abilities as unique legal persons, on the basis of which they enjoy specific legal subjectivity.

The constituent elements of international organizations. International organizations are constituted by formal decisions by states, whose will is embedded in the constitutive instruments of these organizations (Nešović and Jerotijević, 2018, p. 91). Therefore, the legal nature, status and jurisdiction of international organizations depends on the conceptual definition and content of the constituent elements on the basis of which they are established. Costume elements represent the basic common characteristics that make up the unique essence of international organizations. By determining and analyzing the essence of the constituent elements, the international legal subjectivity of organizations, their legal nature, status and scope of activities, respectively, are determined. jurisdiction. First, the constituent element of international organizations are states as the basic creative subject in the process of their creation. The legal nature of inter-national organizations is inter-state, which means that they represent an instrument and institutional framework 
for voluntary cooperation between states, hence the undisputed influence of Member States (Avramov and Kreća, 2008, p. 171). International organizations do not have an independent will, because they can stand alone on the basis of the founding act, entrusted with jurisdiction by the states. Then, countries participate in the work of bodies and other bodies of international organizations that result in binding decisions. These decisions reflect the will and political power of the member states, and the mandate for their implementation is entrusted to the international organizations within which they have been passed. On the other hand, by establishing, or by joining an organization, the states voluntarily committed themselves to adhering to the legal rules that were embedded in a concrete, founding international treaty, thereby limiting some of their rights and undertaking specific obligations. One of the constituent elements is a multilateral international treaty, which is voluntarily concluded and without which an international organization would not exist, as an instrument of its founding. This founding international treaty establishes the basic prerequisites for the existence of an international organization such as: reasons and objectives for establishment, area and competencies, organs and bodies of the organization, manner of dispute settlement between member states, accession procedures, rights and duties of members, etc. As it is an international treaty of constitutive character, some theorists define it as a constitution of an international organization. One key question is raised here: are international organizations the result of purely international contracting or there is another feature of their subjectivity, that is, is the subjectivity of international organizations a mere accumulation of the will of the states (Savić, 2016, p. 182)? It can be said that the subjectivity of international organizations does not represent the accumulation of the will of the states, but implies the autonomy of will, although limited and directly manifested in international legal relations, "international organizations were created to help members deal with issues that each member can not deal with in sovereign isolation" (Blikker and Wessel, p. $1-8,2005)$. "International organizations are not the substratum of states, but the bodies through which the common goals of several states are realized, they do not absorb the complete personality of the state, but through their overall cooperation, their functioning (Lat. corpora), the organization appears as a separate person (Avramov and Kreća, 2008, p. 171)."

Then, the constituent element is the organs of an international organization through which the adopted decisions of the organization are put into operation. For this reason, international organizations, without doubt, determine international legal subjectivity. International organizations, as a rule, have the main, basic organs that represent its pillar, both in formal and factual terms. Depending on the nature of the organization itself, these bodies can be administrative, executive, plenary, advisory, or judicial.

Activity, or competence, can be considered as the following constituent element of an international organization. By the conclusion of the founding international treaty, depending on the nature of the association, the state determines the field of activity, which is usually predetermined by the type of international organization itself. The activities of international organizations are closely related to its goals. Certainly, the intentions of the founding states are crucial, because the states that conclude the founding act by establishing the organization itself determine the competencies of the international organization, on the basis of which a conclusion can be made directly about the existence or non-existence of its international legal subjectivity. Furthermore, in addition to an international treaty, 
it is necessary to adopt and enter into force the statute of an organization that also constitutes a constituent element of an international organization. This document defines the organizational framework of the organization and, above all, refers to the acquisition of the legal personality of an international organization. Together with the founding act that is the basis of the legal capacity of an international organization, it closes the whole of its legal personality. The Statute is most often regulated by the procedures and method of decision making, as well as additional competencies of the body of the organization. It has already been said that an international organization, as a subject of international law, within the limits of its jurisdiction, has its own autonomous will, which differs from the special will of the Contracting States, and is directly responsible for the adoption of its acts and actions undertaken in order to implement them in life. Thus, we come to autonomy, as a constituent element, which together with the above mentioned elements rounds up the international legal subjectivity of international organizations. Although the international organization enjoys its autonomy within the jurisdiction defined by the provisions of the founding treaty, and in accordance with these norms, and outside the framework of the framework loses its legal capacity, its international legal subjectivity is undisputed. Based on its constituent elements within a defined framework, an international organization has legal and business capacity.

\section{Membership in international organizations}

Membership in international organizations implies certain rights and obligations for members of that organization. In other words, by ratifying the founding act, the organization's members accept the rights and obligations arising from it. One of the fundamental rights of the members is to participate in the work of this organization, while their primary duty is to conscientiously implement the decisions of the organization. In the event that a member does not fulfill his obligations to the organization, the organization may take certain measures, from the limitation of some rights to suspension and exclusion. The question is, who can be a member of an international organization? It is indisputable and, at the same time, the rule that states are the most important members of an international organization, either its founders, those who later joined or received it. In its definition of an international organization, for the purposes of the Draft Members' Responsibility, ILC has determined that members of an international organization, in addition to States, may be other international organizations, territories other than independent states and private entities, accepting such an existing trend in practice. This attitude has been accepted by many countries. However, it can be said that these are exemptions from the rules that only states can be members of the organization and this is a presumption for any organization regardless of whether it is provided for by the founding contract or not. Exceptions to this rule (territories that do not have all the features of the state, other international organizations, private entities) must be explicitly envisaged by the founding act.

There are several forms of membership in international organizations: 1) full members who participate in all the activities of the organization and have full scope of rights. Most often, the founding act stipulates that only countries can have this status. In recent times, the founding acts contain the possibility of full membership of other international organizations in them, and less often territories other than independent 
states; 2) Associated Members who can participate in the work of the organization, but do not have a vote in the plenary; 3) partial members are not members of the organization, but are full members of some of its bodies. In the doctrine of international law, it is considered that the form of membership does not affect the very definition of an international organization, but that it concerns the responsibilities of the members. Only when there is a basis for the responsibility of the members in relation to the acts of the organization, then the category of membership becomes relevant. Greater responsibility exists with full members of the international organization, as they enjoy the full range of rights and obligations in relation to affiliated and partial members (Papić, 2011, p. 106).

\section{Dispute resolution within international organizations}

The accelerated development of the world market has contributed to the creation of an extremely dynamic process of the traffic of people, goods and capital. This has contributed to the development of international contractual relations arising from contracts that are tied to at least two countries. The existence of several different legal systems of economic and civil law at the state level is the starting point for the existence of international commercial law in its contemporary form. When a particular factual situation in one legal matter is linked to more such systems, it is necessary to ask which rules to apply. This can be achieved through the rules of international private law, which implies the application of one of the systems of individual states, the selection of which is based on some criteria (collision method) or the application of international uniform legal rules by applying unified (uniform) norms (the substance).

International unification is the process of equalizing legal norms that apply in different countries. For many years now, internationally, efforts have been made to achieve the unification of substantive law in the civil sector, and especially in the economic field. The unification lawmakers start from the thesis that by passing unified unified rules eliminates the space for the emergence of conflicts of law, so the need for the application of collision norms ceases. However, the practice so far has shown that this is not always easy and that there are many temptations on the road to real unification. By adopting uniform rules applicable to contracts concluded in various legal, economic and social systems, the removal of obstacles to the conduct of international business transactions contributes to the development of international traffic and the achievement of legal certainty in general. Therefore, the unification of international contract law has become a permanent tendency for business people, national legislators and legal doctrines. More recently, more and more, instead of unification, we are talking about the harmonization of rights, which does not aim at absolute uniformity, but rather the convergence of legal systems. Harmonization consists in reducing the differences and deviations between national legal systems by determining the results that regulation in a particular area needs to achieve, without imposing funds that will be specifically achieved without imposing the legal text itself. Only in case of harmonization there remains room for the application of collision norms.

In recent decades, regional and world organizations have been created which, among their objectives, explicitly include the equalization or harmonization of private law of the Member States (eg the European Community, NAFTA - The Notrh American Free Trade Agreement, OHADA - Organisation pour Pharmonisation en Afrique du droit 
des affaires, The World Trade Organization). For these organizations, it is characteristic that Member States convey certain, still limited, legislative powers in the area of civil and commercial matters to the organs of an international organization. They make regulations that are applied directly, without ratification, in the Member States or set standards that need to be fulfilled by national legislation in a particular area. It is about the obligation of the harmonization process. Normally within these organizations, a court or institutional arbitration is established to resolve possible disputes by member states regarding the application and interpretation of a unified law, or the harmonization of national law with established standards.

Therefore, the highest merits for equalizing certain segments of civil and commercial law are attributed precisely to certain international organizations. They are mostly intergovernmental organizations, which means that they are their founders and members of the state, or specialized agencies and commissions of these organizations. In addition, an important role belongs to individual non-governmental international organizations and professional associations of traders and businessmen. These organizations and associations are often authors of drafts that are later adopted at international conferences or within intergovernmental international organizations.

The first two multilateral conventions, which regulated certain issues of international arbitration, were brought within the Society of Nations, in Geneva after the First World War. These are the Arbitration Clauses Protocol of 24 September 1923 (Geneva Protocol) and the Convention on the Execution of Foreign Arbitral Awards of 26 September 1927 (Geneva Convention). At the time of their adoption, these documents were of particular importance, since certain barriers to international arbitration were remedied to them. However, the progress that the arbitration will subsequently experience, and which maintain the provisions of the 1958 Convention on the Recognition and Enforcement of Foreign Arbitral Awards (the New York Convention), and the great success of this Convention, has affected the declining significance of the Geneva Protocol and the Geneva Convention.

These two documents no longer apply between States that have signed the New York Convention (Article VII / 2 of the New York Convention); they are perceived in relations between states not bound by the New York Convention, as well as in relations between these states, on the one hand, and states that have ratified the New York Convention, on the other. The New York Convention is the most prestigious and most universal convention in the field of international trade arbitration. This Convention, which has been accepted by 106 countries to date, is being implemented and interpreted by courts of a large number of countries and is the subject of special attention to legal doctrine throughout the world.

Within the framework of regional conventions regulating international trade arbitration, the European Convention on International Trade Arbitration, adopted on 21 April 1961 in Geneva by the UN Economic Commission for Europe, is of particular importance. To date, 26 European countries have joined the Convention. According to the general attitude of the doctrine, the European Convention represents a significant stage in the evolution of international trade arbitrage rights. In the context of the European Convention, the Arrangement on its application should be mentioned in Paris on 17 December 1962 and ratified by six European countries. Under the auspices of the Council of Europe, a European Convention on the Uniform Law in Arbitration Matters of 20 January 1966 was prepared in Strasbourg, which did not enter into force. Of the 
other regional conventions, the Convention on the Settlement of Investment Disputes between States and Citizens of Other States, made in Washington on March 18, 1965 under the auspices of the World Bank, was signed by more than 130 countries.

One of the most important international documents regarding the unification and harmonization of the rules on international trade arbitration is the Model Law on International Trade Arbitration, which was adopted on June 21, 1985 by the UN Commission for International Trade Law (UNCITRAL).

The basic goal of adopting the Model Law was to create clear and comprehensive rules that would reflect the correct and modern standards for international trade arbitration, which could be accepted by various economic and legal systems in the world. In this regard, the UN Resolution of 11 December 1985 states "States are encouraged to take into account this Model Law when they pass or revise their legislation in order to meet the modern needs of international trade arbitration" (Kovačević, 2000, p. 345).

Although differences between national legal systems have sometimes led to complications, the unification of arbitration rules made by the Model Law is now considered as satisfactory. The reason for such success should undoubtedly be sought in the flexible character of harmonization by which this document is distinguished. Unlike uniform laws and international conventions that do not endorse the modification of their rules, the Model Law states that States are only recommended to see its solutions when adopting national laws in this matter. In that sense, each state is free to determine the extent of integration of Model Law into its internal legislation.

Taking the Model-Law solutions, some countries have decided to take a step further in liberalizing rules on international trade arbitration. This was followed by the Dutch legislation in the matter of arbitration after the 1986 reform, as well as the Swiss Federal Law on Private International Law of 1987. Model law has been adopted in a number of legal systems, and to date, more than 20 countries have passed arbitration laws that are, to a greater or lesser extent, based on this model (Australia, Bermuda, Bulgaria, Canada, Cyprus, Egypt, the Netherlands, Hong Kong, Hungary, Mexico, Germany, Nigeria, Peru, Singapore, Switzerland, Tunisia, Ukraine, etc.). They should also be added to eight US states, as well as all provinces and territories of Canada.

\section{Arbitration and arbitration procedure on the example of Serbia}

Arbitration is a special judicial institution where arbitrators chosen by the parties meritoriously resolve their dispute. Arbitration courts are also called "selected courts". The arbitral tribunal is represented, both in national and, more so, in international traffic, because arbitration is faster, less formal than a state court, the dispute is settled in the first instance if the parties have not agreed to oppose the arbitral decision. Arbiters are good connoisseurs of commercial law, they apply applicable regulations, and can, in certain cases, resolve the application of the principle of justice (Lat. ex aequo et bono).

In Serbia, until now, the arbitration trial was rather underdeveloped. The consequence of such a situation is, on the one hand, the overload of the domestic judiciary and, on the other hand, the recruitment of domestic and foreign arbitrators abroad, even in disputes that are significantly related to Serbia.

In Serbia, the Law on Arbitration was adopted on May 25, 2006 ("Službeni glasnik RS", No. 46/2006). The Arbitration Act, in accordance with internationally accepted 
rules, fully regulates all matters of arbitration - the formation of arbitration, arbitration, arbitration decision, as well as its recognition and enforcement before the competent state courts (Vuković, 2001, p. 19).

The law allows for the speedy establishment of independent arbitration courts on the reputation of similar institutions in the most developed countries, so that domestic and foreign investors, as well as other interested parties, primarily in the economy, can entrust the eventual disputes to the resolution of arbitrations in Serbia, with the legal certainty recognized by France, Switzerland and the United States, countries where arbitration is the most developed. The arbitration law is based on the modern arbitration concept and incorporates the arbitration rules of UNICENTRAL as solutions from comparative law, and in particular from the law of France, the United States and Switzerland.

The arbitration law regulates arbitration of disputes without a foreign element (internal arbitration) and with a foreign element (international arbitration). The basis of the arbitration is the agreement of the parties - without this agreement there is no arbitration trial (Pravna enciklopedija, 1979, p. 78).

Arbitration can only be negotiated for arbitrary disputes, i.e. disputes that are similar to being subject to arbitration. This is only about property disputes about the rights freely disposed of by the parties, except for disputes for which the exclusive jurisdiction of the state court is prescribed. Any natural and legal person, who, according to the provisions of the Law on Civil Procedure, has the capacity to be a party to the proceedings, can negotiate an arbitration, including the state, its organs, institutions and companies in which it has ownership interest. Arbitrary dispute resolution is organized by permanent arbitration institutions, in accordance with its rules and the Arbitration Act, as provided for by the agreement of the parties.

The chambers of commerce, professional and professional associations, associations of citizens in accordance with their founding act and the Law on arbitration may establish or organize arbitration, if in accordance with their activity. In addition to permanent arbitration, parties can also establish temporary ad hoc arbitration for resolving a particular dispute.

\section{Arbitration agreement}

An arbitration agreement is defined as an agreement by which parties entrust arbitration to settle their future and arising disputes from a particular legal relationship, which means that arbitration can be arranged at any time, even when the dispute has arisen and when it is brought to the court, but can only contract for a specific legal relationship, or a dispute, and not for all legal relationships between certain persons.

In this way, the supremacy of the state judiciary and the exceptional nature of arbitration are ensured. It is also established that an arbitration agreement may be contained in a contract regulating a legal relationship (arbitration clause) or in a special agreement relating only to arbitration (arbitration agreement).

Agreement is null and void:

1. if the type of disputes to which it relates is not eligible for arbitration,

2. if it is not concluded in the form prescribed by law,

3. if the parties did not have the necessary features and capabilities for its conclusion, 
4. if it is concluded under the influence of coercion, threat, justice or error.

The arbitration agreement must be made in writing, and the prescribed modalities of the written form are prescribed in detail. The agreement remains in force in the case of the transferor of the underlying contract or receivable. If there is a valid arbitration agreement, the court is obliged, on the complaint of the party, to declare itself incompetent and to dismiss the lawsuit in the same matter.

Notwithstanding the existence of an arbitration agreement, before the initiation or during the arbitration proceedings, the court may make a decision on the introduction of provisional measures, at the request of the interested party.

The arbitral tribunal consists of one arbiter (arbitrator) or three or more arbitrators (arbitration panel). If the arbitration agreement provides for more arbiters, their number must be odd.

The number of arbitrators in the arbitral tribunal is determined by the parties. The parties shall also determine the procedure for the appointment of arbitrators by mutual consent. The arbitrator can be any business-capable natural person, regardless of nationality, which has characteristics that require the parties. In particular, the arbitrator must be impartial and independent in relation to the parties and the subject of the dispute.

The arbitrator accepts the duty in writing, and is obliged to inform the parties about all the essential issues related to the performance of his function. The Arbitrator must perform his duty conscientiously and efficiently and may be exempted if he is not impartial or independent or if he does not have the qualities required by the parties, and the procedure for his disqualification, as well as the termination of the function and the appointment of a new arbitrator, are regulated. The arbitral tribunal may also decide on its own jurisdiction, i.e. on complaints of incompetence and overdraft.

\section{Implementation of the arbitration procedure}

The arbitration procedure is regulated by the agreement of the parties, within the limits of the imperative norms, and in particular the essential principles of the procedure, the manner of determining the place of arbitration, the language of the proceedings, the manner of filing a lawsuit and the response to the lawsuit, the moment of initiation of the proceedings, also provides for the possibility of oral and written proceedings, the manner of delivery and receipt of letters, the obligation to notify the parties, objections, the status of witnesses and experts, the assistance of the court in the presentation of evidence, and the manner of ending the arbitration procedure.

The arbitral tribunal shall make the final decision, which shall decide on all the requests of the parties, and may also issue an interdisciplinary or partial decision, which shall decide on the part of their claims. An arbitration decision is made by the application of rights, contracts and customs, and only if the parties explicitly agree on that, the decision may be made by the application of justice and fairness. In international arbitration, the applicable law, that is, the rules, is determined by the agreement of the parties, and in the absence of such agreement, the appropriate right, that is, the rules, is determined by the arbitral tribunal.

The arbitral award shall be made in writing, after a plenary session attended by all arbitrators, but a majority of the votes shall be sufficient for the adoption of the decision. An arbitrator who is not in agreement with the decision can give an opinion. The decision 
must contain an introduction, a statement, an expense, and an explanation, and may also be made on the basis of a settlement. The decision is delivered to the parties, and may be deposited with the court of arbitration if the parties so require. The arbitral tribunal is obliged, at the request of the parties, to correct, interpret or amend the decision.

The domestic arbitration court may annul a decision rendered in the Republic by means of domestic procedural law, regardless of whether it is an internal or international arbitration, only for the reasons prescribed by law, provided that the lawsuit for annulment is filed within three months from the date when the prosecutor received an arbitration award. The court may suspend the conduct of a vote if, at the request of the party, it orders the arbitral tribunal to remove the reasons for the annulment.

The provisions of the Law on the Border Procedure shall apply to the court proceedings on the complaint for the annulment of the arbitral award. The parties can not forego the right to a petition for reprimand in advance. In some cases, the arbitration proceedings may continue even after the decision has been annulled - namely, if the reason for the annulment does not relate to the existence and validity of the arbitration agreement, that agreement remains binding upon the parties until they decide otherwise.

The domestic arbitration award has the power of a domestic final court decision and is enforced in accordance with the provisions of the law governing the enforcement proceedings.

A foreign arbitral decision shall have the power of a domestic final court decision after it has been recognized by the competent court of the Republic. A foreign arbitration decision is a decision taken by an arbitral tribunal whose place is outside the Republic of Serbia, as well as a decision taken by the arbitration tribunal in Serbia, if foreign law was applied to arbitration proceedings.

The Law on Arbitration regulates the jurisdiction and procedure for the recognition and enforcement of foreign arbitration decisions, the grounds for refusing recognition and enforcement, the procedure for awarding an arbitration decision initiated abroad, as well as the content of the decision on recognition and enforcement.

Foreign Trade Arbitration (FTA) (established in 1947) is an institutional (permanent) international economic arbitration of a general type, based in Belgrade, at the Serbian Chamber of Commerce. It resolves disputes of all kinds from international business relationships. FTA Features:

- $\quad$ FTA is an autonomous and private (non-state) judicial authority based on the will of the parties;

- $\quad$ FTA is an international arbitration, independent and independent in its work, which most often resolves disputes between domestic and foreign persons;

- Arbitrators may be domestic and foreign citizens, appointed by the parties, from the list of arbitrators or from outside, and the only president of the arbitration panel must be from the list of arbitrators;

- Disputes are settled by an arbitrator or an arbitration panel composed of three arbitrators, which depends on the will of the parties, and if there is no agreement between the parties, the criterion is the value of the dispute;

- $\quad$ FTA is a general type of arbitration because it resolves all kinds of disputes arising from international business relations;

- $\quad$ FTA is an open-ended arbitration, because both parties can be foreigners. 
FTA's competence:

Foreign trade arbitration, if the parties contracted or accepted its jurisdiction, resolves disputes in which both parties, foreign legal or natural persons and disputes between domestic and foreign legal or natural persons derive from foreign trade and other international business relations (Vuković, 2001, p. 142).

The STA is also responsible for resolving:

1. disputes concerning ships and aircraft, or international disputes to which aviation and navigation law applies,

2. disputes arising from a contract on the establishment of an enterprise and other forms of organization in mixed ownership,

3. disputes arising from a contract on foreign investments,

4. disputes arising out of a concession contract,

5. disputes arising from a contract on intellectual property rights (copyright and related rights, industrial property rights, legal protection of know-how, rights in the field of unfair competition,

6. other disputes in international business relations.

Procedure and decision:

- Foreign trade arbitration shall conduct a conciliation procedure, and if the settlement succeeds, that procedure shall be terminated by settlement by signing the minutes in which it is established that the parties have settled.

- The arbitration procedure is one-sided and, as a rule, lasts for up to one year.

- The arbitral decision is final and there is no appeal against it. It has the force of a final judgment of the ordinary court.

\section{Conclusion}

International organizations have become irreplaceable in the contemporary international legal order. In the world of globalization and other integration processes, they allow for cooperation that goes beyond state borders. However, although they do not possess all the qualities of statehood, the status of international organizations can not be reduced to a mere set of individual will of the member states, but it is much more complex. In addition, the criterion of statehood, in the conditions of modern development of international legal relations, can not be considered as a key to international subjectivity. International law has long since grown into a pure intergovernmental concept, and the notion of an international legal personality has become a much wider concept of an individually recognized state in accordance with the perception of a subjectivity based on sovereignty and the legal order of power. Also, if it is understood that subjects of international law are bearers of international rights and obligations and are directly responsible for disregarding the rights and non-fulfillment of their international legal obligations, then undoubtedly international organizations have legal and business capacity as they exercise their rights in international relations.

It is clear that international organizations have a special international legal subjectivity that differs from the subjectivity defined in internal state law. In the first place, the subjectivity of an international organization depends on the intent of the states that 
conclude the founding act, forming the organization itself. In the event that states intend to establish the existence of an international legal personality of a particular organization, they can incorporate it into the founding act. Nevertheless, it is more often the case that on the basis of the defined objectives, the activities, competencies and rights entrusted to the international organization, the existence of the international legal subjectivity of the organization is carried out. There is no doubt that international organizations represent legal persons in international law, that they are a subject of international law and that they are able, taking into account international demands, to assume in their name rights and obligations in international legal relations.

The practice and doctrine of international law clearly indicate that the subjectivity of international organizations differs from organization to organization and are subject to the impact of specific rules of international law applicable to particular organizations. Alvarez believes that the wrong attempts to establish a general theory of the responsibility of international organizations is based on the existing but still limited concept of their international legal subjectivity. Also, in the last comment of Article 2 (a), the ILC drew attention to the fact that in applying the general principles and rules laid down by the Members' Board on the liability of international organizations, where appropriate, account should be taken of factual and legal circumstances related to the specific organization.

It can be concluded that the role of international organizations within the international legal order, despite the crisis in which international law is today, is gaining in importance. This especially in the conditions of the integration process at the global level, when the others began to develop, as a rule, are more complex forms of international and economic relations. As in any process of full dialectical unity of opposites and the process of integration, especially in the economic sphere, it was burdened with various problems. For example, the formation of a global economy has been influenced primarily by the elements that most contribute to the development of economic forces, both in the technological and economic as well as in the social and political sphere.

The character and complex structure of international relations, especially economic and business, requires a special degree of delicacy in resolving disputes that accompany these relationships. One of the basic motives that determines business people in their contractual relations of international character in the event of a dispute is arbitration, it is reflected in an effort to resolve the dispute equitably and fairly, taking into account professional customs and the relevant rules of the profession.

In addition to resolving specific disputes, this is also significant from another point of view. Namely, through the resolution of certain economic disputes arbitration has a significant impact on the development of the rules of international commercial law. It is understood, to a lesser extent, that the courts also have such influence when dealing with economic disputes. The procedure before the arbitration is not public, which is of importance to the parties given that they are given the opportunity to preserve their business interests and business secrets in spite of their appearance before the court. All these circumstances have made arbitration gaining a dominant role in the field of dispute settlement in the field of international business traffic.

The future of the world economy will depend on solving open issues between certain parts of the world and the speed and the way in which appropriate adjustments will be made, first of all those countries which have dominated the world economy in the past and which have been integrating the world economy, Benefits. 
The future of the world economy will also depend on the relationship between the world population, natural and other resources. Regardless of all open issues and difficulties, the unjustified presence, hunger, misery, poverty and absence of the political will of relevance factors to address issues of interest to the world community for which there is a possibility to resolve, all these shortcomings fall into the shadow of overall economic achievements .

These results represent enormous material strength and provide the basis for expectation of positive results in the development of the world economy. They will be even greater and will help mobilize the forces for further development, if the developmental effects are available in the right way to the global community as a whole. The integration of the world economy should contribute to resolving these issues by integrating these associations into economic development, whereby the abolition of diversity and equality through the privileges of one another is expected over time, thus leveling the level of development, as the tariffs are abolished and other obstacles that burden free trade. For example, Serbia that should join the EU will not automatically become a developed country, but gradually, through the system of free movement of people, capital, labor and other privileges the population of Serbia, and thus the economy will be economically strengthened and slowly drowned in the rest of the EU countries, in terms of economic development (this is an assumption that does not have to be fully accurate).

Finally, it should be emphasized that, no matter how different they may have been, one can not overlook the fact that international organizations have certain common features without which they are not. Subjectivity, which means the question of responsibility should be viewed through the concrete scope of the rights and obligations of a particular organization. Therefore, international organizations, in the extent to which they hold certain rights and obligations, should be held accountable for their violation.

\section{References}

"Službeni glasnik RS", No. 46/2006.

Avramov, S. and Kreća, M. (2008). Međunarodno javno pravo, Beograd.

Blikker, N. M. and Wessel, R. A. (2005). Updating International Organisations, in journal: International Organisations Law Review, no. 2.

Dimitrijević, M., Simić, M. and Đorđević, S. (2006). Uvod u pravo, Kragujevac.

Encyclopedia of Public International Law (1995). Volume II, North-Holland.

European Convention on International Trade Arbitration of 21 April 1961, "Sl. list FNRJ “- Supplement, no. 12/1963.

Geneva Convention on International Trade Arbitration, 1958.

Geneva Protocol on Arbitration Clauses of 1923.

Grupa autora (1979). Pravna enciklopedija, Savremena administracija, Beograd.

Kovačević, S. (2000). Međunarodni ekonomski odnosi, Univerzitet u Kragujevcu, Ekonomski fakultet.

Krivokapić, B. (2011). Aktuelni problemi međunarodnog prava, Beograd. 
Lukić, R. and Košutić, B. (2006). Uvod u pravo, Službeni glasnik, Beograd.

Nešović, D. and Jerotijević, D. (2018). ROLE AND IMPORTANCE OF INTERNATIONAL AGREEMENTS IN REGULATING INTERNATIONAL RELATIONS IN MODERN CONDITIONS, in: journal Економика, no. 3, Niš.

Papić, T. (2011). Pojam međunarodne organizacije iz Nacrta članova o odgovornosti međunarodnih organizacija Komisije UN za međunarodno pravo, in journal: Pravni zapisi, no. 1.

Pravilnik o spoljnotrgovinskoj arbitraži pri Privrednoj komori Srbije (2007).

Savić, M. (2016). Pravna ličnost međunarodnih organizacija, in journal: Politeia, no. 11, Banja Luka.

Starčević, M. (2007). Međunarodno privredno pravo, Prvredna akademija Novi Sad.

Statute of the International Court of Justice, 25 May 1993 Resolution 827) (amended 13 May 1998 Resolution 1166) (as amended on 30 November 2000 Resolution 1329) (amended 17 May 2002 Resolution 1411).

The arbitration rules of UNCITRAL were adopted by the UN Commission on International Trade Law on 15 December 1976.

The Geneva Conventions on the Execution of Foreign Arbitral Awards of 1927.

The UNCITRAL Model Law on Arbitration was adopted by the UN Commission on International Trade Law on June 21, 1985.

Used sites: http://untreaty.un.org/ilc/documentation/english/a_cn 4_101.pdf; http://www. unidroit.org; http://www.ilo.org/; http://www.wipo.org; http://www.coe.int; http:// www.unece.org; http://www.iccwbo.org/; http://www.comitemaritime.org; http:// www.ila-hq.org/; http://www.icj-cij.org/docket/files/4/1835.pdf; http://www.un.org/ law/avl/; www.projuris.org, november 2018.

Visković, N. (2001). Teorija države i prava, Zagreb.

Vukadinović, R. (2006). Pravo Evropske unije, Kragujevac.

Vuković, S. (2011). Komentar Zakona o arbitražnim sporovima, Beograd, 2001. 